\title{
SPIRITUAL NEEDS OF PTSD PATIENTS IN CROATIA AND BOSNIA-HERZEGOVINA: A QUANTITATIVE PILOT STUDY
}

\author{
Andrijana Glavas ${ }^{1}$, Karin Jors ${ }^{1}$, Arndt Büssing ${ }^{2}$ \& Klaus Baumann ${ }^{1}$ \\ ${ }^{1}$ University of Freiburg, Faculty of Theology, Department of Caritas Science and Christian Social Work \\ Freiburg, Germany \\ ${ }^{2}$ University of Witten-Herdecke, Faculty of Medicine, Department of Medical Theory \\ Integrative and Anthroposophical Medicine, Witten, Germany
}

received: 9.8.2016;

revised: 7.3.2017;

accepted: 27.4.2017

\section{SUMMARY}

Background: As a result of the wars in Croatia and Bosnia-Herzegovina, many people have been affected by post-traumatic stress disorder (PTSD). Considering that religion plays an important role in both of these countries and that religiosity/spirituality can be a positive coping resource, we were interested in investigating the spiritual needs of PTSD patients in these countries. Also, we aimed to compare the spiritual needs of war veterans and civilians with PTSD.

Methods: In this cross-sectional study, 120 questionnaires were distributed to civilians and veterans with PTSD at one university hospital in Croatia and in Bosnia-Herzegovina, respectively (response rate: 52.2\%). The sample ranged in age from 35-61 years (average age: $49 \pm 1$ years) and was mostly male (77.8\%). The Spiritual Needs Questionnaire (SpNQ 2.1) was used. Data analysis was conducted using SPSS.

Results: Two-thirds of participants identified themselves as religious and exhibited a variety of spiritual needs. The intensity of spiritual needs (i.e., Religious Needs, Existential Needs, Inner Peace Needs, Giving / Generativity Needs; but also Social Support needs) did not significantly differ between veterans and civilians. PTSD patients who identified themselves as non-religious had significantly lower Religious Needs and Existential Needs; there was also a trend to lower Inner Peace Needs.

Conclusion: Regardless of religious identity, PTSD patients in our study expressed several psychosocial, existential and spiritual needs. A holistic approach to treatment of these patients, which includes psychosocial and spiritual aspects, appears meaningful.

Key words: post-traumatic stress disorder - coping - spiritual care - religious and spiritual needs

\section{INTRODUCTION}

Although the Croatian War of Independence as well as the Bosnian War ended more than twenty years ago, a large part of these countries' populations - children, teens and adults - is still suffering under the physical, emotional, social and even spiritual effects of traumatic war experiences. According to the Croatian Institute for Public Health (2014), 10,137 Croatian men between the ages 50-64 and 19,186 between the ages 30-49 have been diagnosed with post-traumatic stress disorder (PTSD) (Croatian Institute of Public Health 2014). Because the number of PTSD cases is much higher in the male population, it is assumed that most of these cases are war-related. In Bosnia-Herzegovina, a prior study in the district of Tuzla has shown that the number of patients diagnosed with and treated for PTSD increased gradually between 1999 and 2003 (Avdibegovic et al. 2008). This increase in diagnosis and treatment can be seen in a positive light considering that fear of stigmatization often hinders those affected from verbalizing their situation and seeking the necessary help.

Although structures have increasingly been put into place to serve the needs of those affected by PTSD in Croatia and Bosnia-Herzegovina over the last several years, the spiritual needs of this particular population have often been overlooked, also in research in this field. Prior research has revealed that spirituality can be both negatively and positively influenced by the occurrence of traumatic experiences. Whereas a trauma may cause some to turn to their faith for help, others may blame God for their negative experiences or struggle to find meaning in their suffering. Thus, religious beliefs can be linked to both positive and negative coping strategies (Drescher \& Foy 2008, Mihaljević et al. 2012). Positive religious coping has been shown to lead to post-traumatic growth (Shaw et al. 2005). The effects of spirituality on the symptoms of PTSD are also varied - sometimes positive, sometimes neutral or even negative (Hussain et al. 2011, Currier et al. 2015). Among war veterans, one large-scale study of WWII veterans showed that religious activity (e.g. church attendance) was used by many as a positive coping strategy to deal with particularly negative experiences of war (Wansink \& Wansink 2013). A smaller study of veterans from Croatia and Bosnia and Herzegovina also found that veterans who scored higher on an index of religious moral beliefs were able to deal better with distress, had greater mental stability and even had healthier alcohol and tobacco use habits (Hasanovic \& Pajević 2010).

During the wars in Croatia and Bosnia-Herzegovina, religious beliefs played a not unimportant role. Now as well, the majority $(86 \%)$ of the population in Croatia is Catholic, whereas in Bosnia-Herzegovina approximately 
$50 \%$ are Muslim and 30\% Orthodox (Croatian Bureau of Statistics, Federal Bureau of Statistics BosniaHerzegovina). Because religious beliefs generally play an important role in these countries' populations and can also influence and be influenced by the experience of PTSD, we were interested in investigating the religious/spiritual needs of both civilians and war veterans with PTSD in Croatia and Bosnia-Herzegovina. In particular, we aimed to find out:

- What spiritual needs do PTSD patients in these countries have and how strong are they?

- How do these spiritual needs vary according to one's experience of war (i.e., civilian or veteran), gender, religion and other demographic characteristics?

We hypothesized that war veterans who were active in the war would have greater spiritual needs than civilians who were impacted by the war but not active.

The overall goal of this pilot study was to investigate the extent to which religious/spiritual (R/S) experiences and behaviors function as a resource or as a vulnerability factor for PTSD patients. Based on our results, we hope to provide a basis for a more comprehensive treatment of PTSD patients.

\section{SUBJECTS AND METHODS}

\section{Sample}

Between January 2013 and October 2013, a 9-page paper questionnaire with validated instruments was distributed to 120 in- and outpatients being treated for PTSD in the Department of Psychiatry and Psychotherapy at one university hospital in Croatia and in Bosnia-Herzegovina, respectively, as well as at the corresponding centers for PTSD. Inclusion criteria included a primary diagnosis of PTSD (F43.1) as determined by the responsible physician, treatment in an inpatient, outpatient or day clinic and age 18 years or older. Patients with an acute psychosis were excluded from the sample. Additional comorbid diagnoses (e.g. depression) were not excluded as these are frequent among PTSD patients. Both civilians as well as war veterans were recruited, ranging in age from 35-61 (average age: $49 \pm 1$ years). Treating physicians asked patients who met the inclusion criteria to participate in the study. Upon agreeing to participate, the treating physician provided the patient with the questionnaire and also collected the completed questionnaires.

Participants were assured of anonymity and confidentiality. The Ethics Board of the University Medical Center Freiburg as well as the participating university hospitals in Croatia and Bosnia-Herzegovina provided approval for the study.

\section{Instruments}

The measures used for this study were translated from the German original version into Croatian by the first author (AG). The translation from German to
Croatian was then verified by an official public translator. The entire 9-page questionnaire collected data on the following topics: 1) religious and spiritual needs; 2) stress perception; 3) multidimensional life satisfaction; 4) self-efficacy expectation; 5) interpretation of illness; 6) altruism; 7) conscious presence and self-control; 8) symptoms of PTSD; 9) symptoms of depression and anxiety; 10) positive daily structure and well-being. As this article reports only on spiritual and social support needs, we explain here only the measures used to collect data on this topic.

\section{Spiritual Needs Questionnaire (SpNQ 2.1)}

In order to systematically assess the psychosocial, existential and spiritual needs of participants, we chose the Spiritual Needs Questionnaire (SpNQ), which has been used frequently in other comparable studies (Büssing et al. 2010, 2012). The questionnaire consists of 27 diagnostic items and $20+3$ items to calculate the following scales: Religious Needs, Existential Needs, Inner Peace Needs, Giving / Generativity Needs, and as an additional "non-spiritual" category, Social Support Needs. For each item, participants were asked to rate their spiritual needs on a four-point scale (0-none, 1somewhat, 2-strong, 3-very strong). Accordingly, a lower score corresponds to fewer needs. In this sample, the internal consistency of the 20 item construct is high (Cronbach's $\alpha=0.894$ ). The four subscales for spiritual needs are as follows:

\section{Religious Needs}

In this category, patients were asked about their religious activities and needs, i.e. if they feel the need to pray, to pray with someone, that someone prays for them, to read religious books/scriptures, to participate in religious ceremonies, to turn to a higher power (God, angels); additional items not used for the scale calculation included the need to have contact to a minister or to have someone from their religious community (e.g. a minister) care for them. Internal consistency for this 6item subscale was very high (Cronbach's $\alpha=0.915$ ).

\section{Existential Needs}

This category consisted of 5 items about meaning and purpose, i.e., the need to reflect back on life, the need to find meaning in illness and/or suffering, the need to ask about the meaning of life, the need to talk with someone about the possibility of life after death, and the need to forgive someone from a distinct period of life. The need to be forgiven was an additional item but has not been calculated here. In this small sample, the subscale had an acceptable internal consistency (Cronbach's $\alpha=0.637$ ).

\section{Inner Peace Needs}

Five questions were used to assess participants' need to be able to dwell in a quiet and peaceful place, to delve into the beauty of nature, to find inner peace, to resolve unsolved problems from one's life, and to talk with someone about fears and worries. In our sample, 
the subscale had an acceptable internal consistency (Cronbach's $\alpha=0.625$ ).

\section{Giving / Generativity Needs}

This category consisted of four items that addressed participants' need to share their own life experiences, to comfort/solace someone, to turn to someone with a loving attitude, and to know that life was meaningful and valuable. For these four questions, the internal consistency in our sample was high (Cronbach's $\alpha=0.833$ ).

\section{Social Support Needs}

This category addressed relational needs, i.e., the need for connectedness to one's family and the desire to receive support from family members. The internal consistency for the two items in this category was acceptable (Cronbach's $\alpha=0.653$ ).

\section{Spiritual-religious self-categorization}

Apart from their religious denomination, participants were asked whether they assess themselves as a religious and/or spiritual person. For this purpose, we used two items from the SpREUK (acronym for the German translation of "Spiritual and Religious Attitudes in Dealing with Illness") questionnaire, i.e.: "I perceive myself as a religious person" and "I perceive myself as a spiritual person". Both of these items are scaled from
0 to 4 (0: does not apply at all, 1: does not apply for the most part, 2: I can't decide, 3: applies for the most part, 4: completely applies). Participants who answered either 0 to 2 were considered to have provided a negative response (-), whereas participants who answered 3 or 4 were considered to have provided a positive response $(+)$. Thus, participants can be described as religious and spiritual $(\mathrm{R}+\mathrm{S}+)$, neither religious nor spiritual (R-S-), religious but not spiritual $(\mathrm{R}+\mathrm{S}-)$ or spiritual but not religious $(\mathrm{R}-\mathrm{S}+)$. For the purpose of our analysis, we created two groups, one including all religious persons $(\mathrm{R}+\mathrm{S}, \mathrm{R}+\mathrm{S}-)$ and one for all non-religious persons. (R-S+ R-S-) Further subcategorizations were not meaningful due to the low number of participants (i.e., 1 person in the R-S+ group and 8 in the $\mathrm{R}+\mathrm{S}$ - group).

\section{Data Analysis}

Data analysis was conducted using SPSS 20.0. Descriptive statistics were calculated for all items. Differences between group means were measured using ANOVA. Spearman-Rho was used to test for correlations between spiritual needs. Results with $\mathrm{p}<0.05$ were considered significant. For observed correlations, we regarded $r>0.5$ as a strong correlation, $r$ between 0.3 and 0.5 as a moderate correlation, an $r$ between 0.2 and 0.3 as a weak correlation.

Table 1. Characteristics of 63 enrolled persons

\begin{tabular}{|c|c|c|c|}
\hline & & Frequency & $(\%)$ \\
\hline $\begin{array}{l}\text { Status } \\
(n=63)\end{array}$ & $\begin{array}{l}\text { Civilians with PTDS } \\
\text { Veterans with PTDS }\end{array}$ & $\begin{array}{l}20 \\
43\end{array}$ & $\begin{array}{l}31.7 \\
68.3\end{array}$ \\
\hline $\begin{array}{l}\text { Age (years) } \\
(\mathrm{N}=63)\end{array}$ & $\begin{array}{l}<45 \\
45-50 \\
51-55 \\
>55\end{array}$ & $\begin{array}{l}12 \\
16 \\
13 \\
12\end{array}$ & $\begin{array}{l}22.6 \\
30.2 \\
24.5 \\
22.6\end{array}$ \\
\hline $\begin{array}{l}\text { Sex } \\
(N=63)\end{array}$ & $\begin{array}{l}\text { Female } \\
\text { Male }\end{array}$ & $\begin{array}{l}14 \\
49\end{array}$ & $\begin{array}{l}22.2 \\
77.8\end{array}$ \\
\hline $\begin{array}{l}\text { Family status } \\
(\mathrm{N}=62)\end{array}$ & $\begin{array}{l}\text { Married } \\
\text { Living with partner } \\
\text { Divorced } \\
\text { Living alone } \\
\text { Widowed }\end{array}$ & $\begin{array}{r}50 \\
2 \\
2 \\
6 \\
2\end{array}$ & $\begin{array}{r}80.6 \\
3.2 \\
3.2 \\
9.7 \\
3.2\end{array}$ \\
\hline $\begin{array}{l}\text { Education } \\
(\mathrm{N}=61)\end{array}$ & $\begin{array}{l}\text { Through grade } 9 \\
\text { Through grade } 10 \\
\text { High school } \\
\text { Other schools }\end{array}$ & $\begin{array}{r}3 \\
54 \\
2 \\
2\end{array}$ & $\begin{array}{r}4.9 \\
88.5 \\
3.3 \\
3.3\end{array}$ \\
\hline $\begin{array}{l}\text { Religion } \\
(\mathrm{N}=62)\end{array}$ & $\begin{array}{l}\text { Catholic } \\
\text { Muslim } \\
\text { Other }\end{array}$ & $\begin{array}{r}30 \\
32 \\
1\end{array}$ & $\begin{array}{r}47.6 \\
50.8 \\
1.6\end{array}$ \\
\hline $\begin{array}{l}\text { R/S Attitude* } \\
(\mathrm{N}=60)\end{array}$ & $\begin{array}{l}\text { Religious ( } \mathrm{R}+\mathrm{S}+\text { and } \mathrm{R}+\mathrm{S}-) \\
\text { Non-Religious (R-S- and R-S }+ \text { ) }\end{array}$ & $\begin{array}{l}40 \\
20\end{array}$ & $\begin{array}{l}66.7 \\
33.3\end{array}$ \\
\hline
\end{tabular}




\section{RESULTS}

\section{Participants}

Of 120 questionnaires that were distributed to PTSD patients (60 for war veterans, 60 for civilians), 63 questionnaires were returned (response rate: $52.2 \%$ ). The response rate was considerably higher among war veterans $(71.6 \%)$ than among civilians $(33.3 \%)$. All questionnaires could be included in the analysis.

Within our sample, 43 participants $(68.3 \%)$ had actively participated in the war and were affected by PTSD, and $20(31.7 \%)$ were civilians affected by PTSD. Over three-quarters $(77.8 \%)$ of the participants were male, and the mean age of the participants was 49 years (range: $35-61, \mathrm{SD}=1.05$ ). At the time of the war, the average age of the participants was 27 years and $22.6 \%$ of those surveyed had not yet reached adulthood. The majority of participants $(80.6 \%)$ was currently married and had children $(85.7 \%)$. Also, most had at least a high school education $(88.5 \%)$. Over two-thirds of participants $(66.7 \%)$ viewed themselves as religious and/or spiritual, whereas about one-third (33.3\%) indicated that they were neither spiritual nor religious (R-S-). More detailed participant information can be found in Table 1 .

\section{Spiritual Needs in the Sample}

As shown in Table 2, the strongest spiritual needs in this sample were for Inner Peace and Social Support, followed by Existential Needs and Giving/Generativity Needs. Religious Needs scored lowest in the sample (but nevertheless high). There were no significant gender differences or differences between former soldiers and civilians (Table 2). Further, there were no significant differences related to the educational level, family status or between Christians and Muslims (data not shown). With respect to age, there were some significant differences for Existential Needs $(F=4.5 ; \mathrm{p}=0.007)$ and Giving/Generativity Needs $(\mathrm{F}=4.1 ; \mathrm{p}=0.011)$ which were lowest in persons aged between 45 and 55 years.

Two-thirds of the enrolled persons regarded themselves as religious and one-third as non-religious, with similar proportions in both religious groups (i.e., $31 \%$ of Catholics and $36 \%$ of Muslims regard themselves as non-religious). As shown in Table 2, non-religious persons had significantly lower Religious and Existential Needs; there was also a (non-significant) trend toward lower Inner Peace Needs among non-religious persons. However, the groups do not significantly differ in regard to Giving/Generativity Needs and Social Support Needs.

Table 3 provides information on responses to the individual items within each category. Frequency and percentages are based on the number of veterans and civilians who indicated strong/very strong needs for each item. In the category Inner Peace Needs, which overall scored highest, nearly $98 \%$ of veterans and $90 \%$ of civilians indicated a strong need to "dwell in a quiet and peaceful place". In regard to Existential Needs, there was a stronger response to the items "to reflect back on one's life" and "to find meaning in one's suffering" for both veterans and civilians compared to the items

Table 2. Intensity of Spiritual and Social Support Needs in the Sample (by Category)

\begin{tabular}{|c|c|c|c|c|c|c|}
\hline & & $\begin{array}{l}\text { Religious } \\
\text { Needs }\end{array}$ & $\begin{array}{c}\text { Existential } \\
\text { Needs }\end{array}$ & $\begin{array}{c}\text { Inner Peace } \\
\text { Needs }\end{array}$ & $\begin{array}{c}\text { Giving / } \\
\text { Generativity Needs }\end{array}$ & $\begin{array}{c}\text { Social Support } \\
\text { Needs } \\
\end{array}$ \\
\hline $\begin{array}{l}\text { All } \\
(n=63)\end{array}$ & $\begin{array}{l}\text { mean } \\
\text { SD }\end{array}$ & $\begin{array}{l}1.72 \\
0.94\end{array}$ & $\begin{array}{l}1.87 \\
0.67\end{array}$ & $\begin{array}{l}2.35 \\
0.56\end{array}$ & $\begin{array}{l}1.85 \\
0.85\end{array}$ & $\begin{array}{l}2.31 \\
0.83\end{array}$ \\
\hline \multicolumn{7}{|c|}{ Veterans / Civilians } \\
\hline $\begin{array}{l}\text { Civilians } \\
(\mathrm{n}=20)\end{array}$ & $\begin{array}{l}\text { mean } \\
\text { SD }\end{array}$ & $\begin{array}{l}1.87 \\
0.91\end{array}$ & $\begin{array}{l}1.89 \\
0.82\end{array}$ & $\begin{array}{l}2.29 \\
0.63\end{array}$ & $\begin{array}{l}2.06 \\
0.81\end{array}$ & $\begin{array}{l}2.55 \\
0.86\end{array}$ \\
\hline $\begin{array}{l}\text { Veterans } \\
(n=43)\end{array}$ & $\begin{array}{l}\text { mean } \\
\text { SD }\end{array}$ & $\begin{array}{l}1.65 \\
0.95\end{array}$ & $\begin{array}{l}1.86 \\
0.59\end{array}$ & $\begin{array}{l}2.38 \\
0.53\end{array}$ & $\begin{array}{l}1.75 \\
0.86\end{array}$ & $\begin{array}{l}2.20 \\
0.80\end{array}$ \\
\hline $\begin{array}{l}F \text { value } \\
P \text { value }\end{array}$ & & $\begin{array}{l}0.70 \\
\text { n.s. }\end{array}$ & $\begin{array}{l}0.00 \\
\text { n.s. }\end{array}$ & $\begin{array}{l}0.40 \\
\text { n.s. }\end{array}$ & $\begin{array}{l}1.90 \\
\text { n.s. }\end{array}$ & $\begin{array}{l}2.50 \\
\text { n.s. }\end{array}$ \\
\hline \multicolumn{7}{|l|}{ Gender } \\
\hline $\begin{array}{l}\text { Women } \\
(\mathrm{n}=14)\end{array}$ & $\begin{array}{l}\text { mean } \\
\text { SD }\end{array}$ & $\begin{array}{l}1.90 \\
0.96\end{array}$ & $\begin{array}{l}2.00 \\
0.76\end{array}$ & $\begin{array}{l}2.31 \\
0.64\end{array}$ & $\begin{array}{l}2.00 \\
0.79\end{array}$ & $\begin{array}{l}2.57 \\
0.83\end{array}$ \\
\hline $\begin{array}{l}\begin{array}{l}\text { Men } \\
(n=49)\end{array} \\
\text { F value } \\
\text { P value }\end{array}$ & $\begin{array}{l}\text { mean } \\
\text { SD }\end{array}$ & $\begin{array}{c}1.66 \\
0.93 \\
0.70 \\
\text { n.s. }\end{array}$ & $\begin{array}{c}1.83 \\
0.64 \\
0.70 \\
\text { n.s. }\end{array}$ & $\begin{array}{c}2.36 \\
0.54 \\
0.10 \\
\text { n.s. }\end{array}$ & $\begin{array}{c}1.80 \\
0.86 \\
0.60 \\
\text { n.s. }\end{array}$ & $\begin{array}{l}2.23 \\
0.82 \\
1.80 \\
\text { n.s. }\end{array}$ \\
\hline \multicolumn{7}{|c|}{ Religious self-perception } \\
\hline $\begin{array}{l}\text { Religious } \\
(\mathrm{n}=40)\end{array}$ & $\begin{array}{l}\text { mean } \\
\text { SD }\end{array}$ & $\begin{array}{l}2.17 \\
0.69\end{array}$ & $\begin{array}{l}2.00 \\
0.69\end{array}$ & $\begin{array}{l}2.46 \\
0.51\end{array}$ & $\begin{array}{l}1.98 \\
0.79\end{array}$ & $\begin{array}{l}2.49 \\
0.75\end{array}$ \\
\hline $\begin{array}{l}\text { Non-religious } \\
(\mathrm{n}=20)\end{array}$ & $\begin{array}{l}\text { mean } \\
\text { SD }\end{array}$ & $\begin{array}{l}0.84 \\
0.70\end{array}$ & $\begin{array}{l}1.63 \\
0.48\end{array}$ & $\begin{array}{l}2.18 \\
0.62\end{array}$ & $\begin{array}{l}1.66 \\
0.93\end{array}$ & $\begin{array}{l}2.00 \\
0.90\end{array}$ \\
\hline$F$ value & & $\begin{array}{l}50.10 \\
<0001\end{array}$ & 4.60 & 3.30 & 1.90 & 4.90 \\
\hline
\end{tabular}


Table 3. Individual Item Responses for Strong/Very Strong Spiritual and Social Support Needs among War Veterans and Civilians

\begin{tabular}{|c|c|c|c|c|}
\hline \multirow{2}{*}{ Item } & \multicolumn{2}{|c|}{ Veterans $(\mathrm{N}=43)^{*}$} & \multicolumn{2}{|c|}{ Civilians $(\mathrm{N}=20)^{*}$} \\
\hline & Frequency & $\%$ & Frequency & $\%$ \\
\hline \multicolumn{5}{|l|}{ Religious Needs } \\
\hline To turn to a higher power & 33 & 76.8 & 17 & 85.0 \\
\hline To read religious books & 23 & 54.7 & 15 & 75.0 \\
\hline To participate in religious celebrations & 23 & 53.5 & 13 & 68.4 \\
\hline To pray on one's own & 26 & 61.9 & 13 & 65.0 \\
\hline To be prayed for & 14 & 32.6 & 7 & 36.8 \\
\hline To pray with someone & 20 & 46.5 & 10 & 52.6 \\
\hline \multicolumn{5}{|l|}{ Giving/Generativity Needs } \\
\hline To share one's own life experiences & 26 & 61.9 & 8 & 68.4 \\
\hline To know that one's life was meaningful and valuable & 30 & 69.8 & 10 & 75.0 \\
\hline To be able to comfort/solace someone & 23 & 54.8 & 12 & 63.2 \\
\hline To turn to someone in a loving attitude & 20 & 47.6 & 15 & 79.0 \\
\hline \multicolumn{5}{|l|}{ Inner Peace Needs } \\
\hline To delve into the beauty of nature & 33 & 76.7 & 9 & 45.0 \\
\hline To dwell in a quiet and peaceful place & 42 & 97.7 & 18 & 90.0 \\
\hline To find inner peace & 36 & 83.7 & 18 & 90.0 \\
\hline To resolve unsolved problems & 34 & 79.1 & 13 & 62.5 \\
\hline To talk with someone about fears and worries & 33 & 76.5 & 16 & 80.0 \\
\hline \multicolumn{5}{|l|}{ Existential Needs } \\
\hline To reflect back on one's life & 36 & 83.7 & 17 & 85.0 \\
\hline To find meaning in one's illness/suffering & 36 & 83.8 & 14 & 70.0 \\
\hline To ask what the meaning of life is & 32 & 74.5 & 9 & 47.4 \\
\hline To speak with someone about the possibility of life after death & 17 & 40.5 & 10 & 52.6 \\
\hline To forgive someone from a distinct period of your life & 18 & 41.9 & 13 & 68.4 \\
\hline \multicolumn{5}{|l|}{ Social Support Needs } \\
\hline To be connected to one's family & 34 & 81.0 & 18 & 90.0 \\
\hline To receive support from one's family & 33 & 76.7 & 18 & 90.0 \\
\hline
\end{tabular}

Table 4. Correlations between Respective Needs

\begin{tabular}{lcccc} 
& $\begin{array}{c}\text { Religious } \\
\text { Needs }\end{array}$ & $\begin{array}{c}\text { Existential } \\
\text { Needs }\end{array}$ & $\begin{array}{c}\text { Inner Peace } \\
\text { Needs }\end{array}$ & \multicolumn{2}{c}{ Giving / Generativity } \\
& 1.000 & $0.506^{* *}$ & $0.336^{* *}$ & $0.315^{*}$ \\
Religious Needs & & 1.000 & $0.647^{* *}$ & $0.522^{* *}$ \\
Existential Needs & & & 1.000 & $0.622^{* *}$ \\
Inner Peace Needs & & & 1.000 \\
Giving / Generativity Needs & & & $0.329^{* *}$ & $0.565^{* *}$ \\
Social Support Needs & $0.547^{* *}$ & $0.538^{* *}$ & & \\
\hline
\end{tabular}

$* \mathrm{p}<0.05 ; \quad * * \mathrm{p}<0.01$

"to speak with someone about the possibility of life after death" and "to forgive someone from a distinct period of your life" (Table 3). Also, while $74.5 \%$ of veterans indicated a strong need to "ask what the meaning of life is" only $47.4 \%$ of civilians responded likewise. In the category Giving/Generativity Needs, both veterans and civilians $(69.8 \%$ and $75.0 \%$, respectively) indicated a strong need to "know that one's life was meaningful and valuable". For the item "to turn to someone in a loving attitude", $79.0 \%$ of civilians indicated a strong need whereas only $47.6 \%$ of veterans responded likewise. Religious Needs, which scored lowest overall, varied considerably for each item within the category. While $76.8 \%$ of veterans and $85.0 \%$ of civilians indicated a strong need to "turn to a higher power", only $32.6 \%$ of veterans and $36.8 \%$ of civilians indicated a strong need to "be prayed for". The need to "pray with someone", while slightly greater, was strong for $46.5 \%$ of veterans and $52.6 \%$ of civilians.

Within the sample, the respective spiritual needs were moderately to strongly interrelated and also moderately to strongly related to Social Support Needs (Table 4). Existential and Inner Peace Needs were most strongly correlated $(\mathrm{r}=0.647, \mathrm{p}<0.01)$. The weakest correlation was found between Religious and Giving/ Generativity Needs $(\mathrm{r}=0.315, \mathrm{p}<0.05)$. 


\section{DISCUSSION}

This study aimed to evaluate spiritual needs and their presence and presumable role in the coping process of traumatized veterans and civilians in Croatia and Bosnia-Herzegovina. Results of this study show that the majority of participants identified themselves as religious. Only one-third of participants considered themselves non-religious. Perhaps this high ratio of religious participants is not surprising since religion has played an important role in both the history and society of Croatia and Bosnia-Herzegovina. It is notable, however, that there is no significant difference between religious and non-religious persons in regard to Inner Peace Needs, Giving/Generativity Needs and Social Support Needs. This indicates that although some people may identify themselves as non-religious, they may still in fact have spiritual needs that deserve attention. For this reason, it appears necessary to do more than simply ask if the person is religious or to inquire about religious denomination when taking a patient's history, as has been common practice in Croatia and in Bosnia-Herzegovina. In recent years, concise, helpful tools have been created to take a more meaningful and comprehensive spiritual history (Luchetti et al. 2013). Taking a spiritual history is the first step toward being able to address patients' individual spiritual needs. However, previous studies in Germany and the USA have shown that psychiatric staff members are open to discussing religious/spiritual issues when patients bring up these issues but are unlikely to proactively address these topics without patients' initiative (Lee et al. 2015, Curlin et al. 2007). Based on the results of our study, we suggest that psychiatric staff may also include an adequate spiritual history in the standard care of PTSD patients, even if patients do not address these issues themselves.

Contrary to our hypothesis, we did not find any significant differences between the spiritual needs of veterans and civilians with PTSD. Among civilians, Social Support Needs were rated highest, followed by Inner Peace and Giving/Generativity Needs. Veterans scored Inner Peace Needs highest, followed by Social Support and Giving/Generativity Needs. These findings are similar to those of a similar study conducted with German soldiers which also found that Inner Peace Needs and "relational" needs were considered most important (Büssing \& Recchia 2016). Looking at the single item responses for Inner Peace Needs, the need to "dwell in a quiet and peaceful place" was scored highest in both groups, with nearly all participants indicating a strong need. Interestingly, however, the need to "resolve unsolved problems" was somewhat more prevalent among veterans $(79.1 \%)$ than civilians $(62.5 \%)$, which may be related to the veterans' direct and active involvement in the war. Although Inner Peace Needs were rated highest in the German study by Büssing \& Recchia, only $30 \%$ of the active German soldiers indicated a strong need to "talk about fears and worries". In contrast, $76.5 \%$ of veterans in our sample had a strong need "to talk about fears and worries". This is likely due to the fact that our sample consisted of veterans affected by PTSD, whereas the German sample of active soldiers had a very low PTSD score, as measured by the PCL-M. Moreover, not all of the German soldiers were directly involved in war-related missions. The German study by Büssing \& Recchia also found that Inner Peace Needs may be related to soldiers' Life Satisfaction; the correlation was negative, meaning that lower Life Satisfaction was associated with higher Inner Peace needs and vice versa (Büssing \& Recchia 2016). Thus, low life satisfaction may bring up these Inner Peace Needs.

In this current paper, we have evaluated Social Support Needs in terms of family support. For both items in this category, i.e., "to be connected to one's family" and "to receive support from one's family", over threequarters of veterans and civilians in our sample indicated strong needs. In the category Giving/Generativity Needs, approximately three-quarters of veterans and civilians had a strong need to "know that one's life was meaningful and valuable". A previous study about spiritual well-being among Croatian war veterans also found that a poor existential well-being (i.e. the ability to find meaning in life and one's illness) was linked to higher suicide rates among this population. As stressed by the authors of the aforementioned study, it appears that finding meaning is one of the most important factors in helping veterans effectively cope with their experience ( $\mathrm{Nad}$ et al. 2008). This aligns with Antonovsky's salutogenic model in which he asserts that meaningfulness is the most important aspect of maintaining a sense of coherence (Antonovsky 1981).

For the item "to turn to someone in a loving attitude" in the category Giving/Generativity Needs, less than half of the veterans indicated a strong need whereas over three-quarters of civilians found this to be an important need. This may be an indication of veterans' disappointment: a lack of recognition and understanding for veterans' situation within society and even their own social circles may result in a need for someone to first turn to them in a loving attitude (Ljubotina et al. 2007).

Religious Needs were scored lowest by both the veteran and civilian PTSD group, although veterans had somewhat lower Religious Needs than the civilian group. However, compared to a German sample of chronically ill patients (Büssing 2012, 2015) as well as to the sample of German soldiers (Büssing \& Racchia 2016), our sample had quite strong Religious Needs. For example, $76.8 \%$ of veterans and $85.0 \%$ of civilians had a strong need to "turn to a higher power" in our sample. Among the German soldiers, only $10 \%$ of the sample responded likewise (Büssing \& Racchia 2016). The relatively high intensity of Religious Needs within our sample is likely the result of the overall religious landscape in Croatia and Bosnia-Herzegovina, where religion has played an important role in society and 
history. In a sample of chronically ill patients in Poland, which is considered a very Catholic country, Religious Needs were even higher than in our sample (Büssing et al. 2015). Among the Religious Needs, the need to "turn to a higher power" was strong among the majority of veterans and civilians. It is quite interesting that participants overall perceive a greater need to "pray on one's own" rather than to "be prayed for" or to "pray with someone". In a literature review of chronically ill patients and prayer, the authors found that prayer, although focused on illness, was not used merely in hopes of being healed but rather as a resource to positively transform the experience of their illness (Jors et al. 2015). Perhaps for this reason, personal prayer is viewed as providing a greater source of comfort. On the other hand, it is also possible that PTSD patients (like others) experience shame when asking for (spiritual) support from others and therefore indicated lower needs for prayer with or from others (Saraiya \& Lopez-Castro 2016).

One study of Croatian war veterans who participated in an intensive one-year group psychotherapy treatment showed no significant improvement on symptoms, except for intrusion (Ljubotina et al. 2007). In this treatment intervention, both supportive and dynamic approaches were applied without considerable effects. These results lead to the question of what other therapeutic approaches may be more beneficial for this population. Based on the described religious/spiritual needs of a majority of participants in our study, it seems likely that patients may benefit from more adequate spiritual support. Although there is little research on spiritually-based forms of therapy, models do exist. For example, a spiritual group therapy approach has been implemented for PTSD patients in Bosnia-Herzegovina (Hasanović et al. 2011). This form of group psychotherapy, which was open to people of all spiritual/ religious convictions, addresses many of the spiritual/ religious needs that were assessed in our study. In the group setting, participants' needs to share their own experiences, to comfort someone or to give something of oneself (i.e. Needs for Giving and Generativity) are well met. Moreover, Religious Needs and Needs for Existential Meaning and Reflection are also addressed through an environment that provides a space to develop and be strengthened in one's relationship to God and also reflect upon fears and worries related to the past. Finally, in a society in which those affected by PTSD often feel stigmatized, being part of a group fosters feelings of acceptance.

To best address the spiritual/religious needs of PTSD patients, it may also be helpful to implement approaches used in other fields of medicine, such as palliative care or treatment of suicidal patients. For example, spiritual exercises (i.e. mindfulness-based and contemplative practices) have been translated into a (secular) set of behavioral skills and successfully implemented in dialectic behavior therapy (DBT) for suicidal patients (Linehan and Wilks 2015; Baumann
2016). Also, similar to PTSD patients, palliative care patients faced with a life-threatening, incurable illness often suffer from demoralization, that is, a feeling of hopelessness due to a loss of their sense of meaning in life (Grassi \& Nanni 2016). One approach that has been developed for use in palliative care patients is Dignity Therapy (Chochinov 2005). In this form of short-term therapy, patients are interviewed about topics that are intended to restore their sense of dignity, such as achievements in their life, important roles they have played and moments when they felt most alive. The interviews are recorded and transcribed so that the contents can be passed along or left behind for family and friends. In the Dignity Therapy model, this is part of the theme "Giving/Generativity", which we also identified in our study as an important spiritual need. It seems feasible that a similar form of therapy could be effective for PTSD patients. Finally, palliative care uses a multi-professional team approach for the treatment of physical, psychological, social and spiritual needs (Palliative Care Definition, WHO 2002). One study involving American veterans found that although nearly $50 \%$ of those surveyed reported being somewhat or very likely to seek out help from a spiritual counselor, only $12 \%$ actually had contact to a spiritual counselor and $10 \%$ had been asked by their VA (Veterans Affairs) providers about spiritual support (Bonner et al. 2013). This seems to demonstrate a need for an increased integration of spiritual care providers into the healthcare team as well as training for health care providers in providing spiritual care.

Finally, one must keep in mind that many victims of trauma are reluctant to seek out treatment in general (Kantor et al. 2017). This may be aided by more direct support from other members of the military who are trained in dealing with trauma and can perhaps relate to veterans in a different way than medical personnel. In the study of German soldiers, $37 \%$ expressed a strong need for more support from military supervisors (Büssing \& Recchia 2016). While this need may be related to other issues as well, it seems that support from other members of the military may be important.

\section{Limitations}

The sample size for this study was comparatively small, making comparisons between groups (e.g. veterans vs. civilians) difficult. However, this was a pilot study. Currently, a full-scale study is underway using the same instruments. We are interested, among other questions, in whether the results of our preliminary pilot study can be replicated in a larger sample. A further potential weakness of this study is that only patients being treated in the hospital setting have been included. Because of stigmatization, not all who suffer from PTSD seek out treatment, but rather try to make it on their own. In the study currently underway, we have also included additional hospitals in hope of reaching as many people as possible. 


\section{CONCLUSION}

Until now, spiritual aspects in the treatment of PTSD patients have received comparatively little attention in research. Our study provides empirical evidence for the importance of more research and more comprehensive, holistic treatment of these patients, according to the biopsycho-social treatment model. Spirituality may act as an important resource for many PTSD patients, especially among veterans and civilians in Croatia and Bosnia-Herzegovina.

\section{Acknowledgements:}

The pilot study is registered in DRKS as DRKS 00004185 (German Clinical Trials Register).

Conflict of interest: None to declare.

\section{Contribution of individual authors:}

Andrijana Glavas: design of the study, recruitment and collection of data, literature searches and analyses, statistical analyses, interpretation of data, writing of the report;

Karin Jors: literature searches and analyses, interpretation of data, writing of the report and corrections as American native speaker;

Arndt Büssing: design of the study, statistical analyses, interpretation of data, writing of the report;

Klaus Baumann: design of the study, literature searches and analyses, interpretation of data, writing of the report.

\section{References}

1. Antonovsky A: Health, Stress and Coping. Jossey-Bass, San Francisco, 1981.

2. Avdibegovic E, Hasanovic M, Selimbasic Z, Pajevic I, Sinanovic O: Mental Health Care of Psychotraumatized Persons in Post-War Bosnia and Herzogovina- Experiences from Tuzla Canton. Psychiatr Danub 2008; 20:474-484.

3. Baumann K: Überlegungen zu Spiritualität und Gebet im Kontext von Krankheit. In: Arnold M, Thull P (Eds.): Theologie und Spiritualität des Betens. Handbuch Gebet. Freiburg: Herder 2016, 363-375.

4. Bonner L, Lanto A, Bolkan C et al.: Help-Seeking from Clergy and Spiritual Counselors Among Veterans with Depression and PTSD in Primary Care. J Relig Health 2013; 52:707-718.

5. Büssing A, Ostermann T, Matthiessen PF: Role of religion and spirituality in medical patients: confirmatory results with the SpREUK questionnaire. Health Qual Life Outcomes 2005; 3:10.

6. Büssing A, Balzat HJ, Heusser P: Spiritual needs of patients with chronic pain diseases and cancer Validation of the spiritual needs questionnaire. Eur J Med Res 2010; 15:266-273.

7. Büssing A, Janko A, Kopf A, Lux EA, Frick E: Zusammenhänge zwischen psychosozialen und spirituellen Bedürf- nissen und Bewertung von Krankheit bei Patienten mit chronischen Erkrankungen. Spiritual Care 2012; 1:57-73.

8. Büssing A, Pilchowska I, Surzykiewicz J: Spiritual Needs of Polish Patients with Chronic Diseases. J Relig Health 2015; 54:1524-1542.

9. Büssing A, Surzykiewicz J, Zimowski Z: Psychosoziale und spirituelle Bedürfnisse chronisch Kranker, Dem Gutes tun, der leidet. Hilfe kranker Menschen-interdisziplinär betrachtet. Berlin, Heidelberg: Springer Verlag 2015.

10. Büssing A, Recchia DR: Spiritual and Non-spiritual Needs Among German Soldiers and their Relation to Stress Perception, PTDS Symptoms, and Life Satisfaction Results from a Structural Equation Modeling Approach. Journal of Religion and Health, 2016; 55:747-764; Online June 2015 (DOI 10.1007/s10943-015-0073-y)

11. Chochinov H, Hack $T$, Hassard T, Kristjanson L, McClement S, Harlos M: Dignity Therapy: A Novel Psychotherapeutic Intervention for Patients Near the End of Life. J Clin Oncol 2005; 23:5520-5525.

12. Croatian Bureau of Statistics. www.dzs.hr. Last visited on 19.07.2016.

13. Croatian Institute of Public Health, 2014. www.hzjz.hr. Last visited on 19.07.2016.

14. Curlin F, Lawrence R, Odell S, Chin M, Lantos $J$ et al.: Religion, Spirituality, and Medicine: Psychiatrists' and Other Physicians' differing Observations, Interpretations, and Clinical Approaches." Am J Psychiatry 2007; 164:1825-31.

15. Currier J, Holland J, Drescher K: Spirituality Factors in the Prediction of Outcomes of PTSD Treatment for U.S. Military Veterans. J Trauma Stress 2015; 28:57-64.

16. Drescher K, Foy D: When They Come Home: Posttraumatic Stress, Moral Injury, and Spiritual Consequences for Veterans. In: Reflective Practice: Formation and Supervision in Ministry, 2008.

17. Federal Bureau of Statistics Bosnia-Herzogovina. www. fzs.ba. Last visited on 19.07.2016.

18. Frick E, Riedner C, Fegg MJ, Hauf S, Borasio GD: A Clinical Interview Assessing Cancer Patients' Spiritual Needs and Preferences. Eur J Cancer Care 2006; 15:238-243.

19. Grassi L, Nanni MG: Demoralization syndrome: New insights in psychosocial cancer care. Cancer 2016; 122:2130-3.

20. Hasanović M, Pajević I: Religious Moral Beliefs as Mental Health Protective Factor of War Veterans Suffering from PTSD, Depressiveness, Anxiety, Tobacco and Alcohol Abuse in Comorbidity. Psychiatr Danub 2010; 22:203-210.

21. Hasanović M, Sinanović O, Pajević I, Agius M: The Spiritual Approach to Group Psychotherapy Treatment of Psychotraumatized Persons in Post-War Bosnia and Herzegovina. Religions 2011; 2:330-344.

22. Hussain A, Weisaeth L, Heir T: Changes in religious beliefs and the relation of religiosity to posttraumatic stress and life satisfaction after a natural disaster. Soc Psychiatry Psychiatr Epidemiol 2011; 46:1027-1032.

23. Jors K, Büssing A, Hvidt NC, Baumann K: Personal Prayer in Patients Dealing with Chronic Illness: A Review of the Research Literature. ECAM 2015; 20: Article ID 927973.

24. Kantor V, Knefel M, Lueger-Schuster B: Perceived barriers and facilitators of mental health service utilization in adult trauma survivors: A systematic review. Clin Psychol Rev 2017; 52:52-68. 
25. Lee E, Zahn A, Baumann K: How do Psychiatric Staffs Approach Religiosity/Spirituality in Clinical Practice? Differing Perceptions among Psychiatric Staff Members and Clinical Chaplains. Religions 2015; 6:930-947.

26. Linehan MM, Wilks CR: The Course and Evolution of Dialectic Behavior Therapy. American Journal of Psychotherapy 2015; 69:97-110.

27. Ljubotina D, Pantić Z, Frančišković T, Mladić M; Priebe, S: Treatment Outcomes and Perception of Social Acknowledgment in War Veterans: Follow-up Study. Croat Med J 2007; 48:157-66.

28. Lucchetti G, Bassi R, Lucchetti A: MD Taking Spiritual History in Clinical Practice: A Systematic Review of Instruments. Explore (NY) 2013; 9:159-70.

29. Mihaljević S, Aukst-Margetić B, Vuksan-Ćusa B, Koić E, Milošević M: Hopelessness, Suicidality and Religious Coping in Croatian War Veterans with PTSD. Psychiatr Danub 2012; 24:292-297.

30. Nad S, Marčinko D, Vuksan-Ćusa B, Jakovljević M,
Jakovljević G: Spiritual Well-Being, Intrinsic Religiosity, and Suicidal Behavior in Predominantly Catholic Croatian War Veterans With Chronic Posttraumatic Stress Disorder: A Case Control Study. J Nerv Ment Dis 2008; 196:79-83.

31. Saraiya T, Lopez-Castro T: Ashamed and Afraid: A Scoping Review of the Role of Shame in Post-Traumatic Stress Disorder (PTSD). J Clin Med 2016; 5:94.

32. Shaw A, Joseph S, Linley PA: Religion, spirituality, and posttraumatic growth: a systematic review. Mental Health, Religion \& Culture 2005; 8:1-11.

33. Wansink B, Wansink CS. Are there atheists in foxholes? Combat intensity and religious behavior. $J$ Relig Health 2013; 52:768-779.

34. World Health Organization: WHO Definition of Palliative Care 2002. Available online:

https://www.dgpalliativmedizin.de/images/stories/WHO_D efinition_2002_Palliative_Care_englisch-deutsch.pdf. Last visited on $15.02 .201 \overline{7}$.

Correspondence:

Prof. Dr. Klaus Baumann

University of Freiburg, Faculty of Theology

Department of Caritas Science and Christian Social Work

Platz der Universität 3, D-79098 Freiburg, Germany

E-mail:klaus.baumann@theol.uni-freiburg.de 